\title{
Small Scale Pig Farming in Manipur, India: A Study on Socio-Personal and Socio-Economical Status of the Small Scale Tribal Farming Community
}

\author{
N. Muhindro Singh ${ }^{1}$, Soibam Basanta Singh ${ }^{2}$ and Soibam Khogen Singh ${ }^{3 *}$ \\ ${ }^{1}$ SMS (Veterinary Science), Krishi Vigyan Kendra, Hengbung, \\ Senapati - 795129, Manipur, India \\ ${ }^{2}$ Directorate of Instruction, Central Agricultural University (Imphal), \\ Lamphelpat, Manipur, India \\ ${ }^{3}$ College of Fisheries, Central Agricultural University (Imphal), Lembucherra, Tripura, India \\ *Corresponding author
}

\section{A B S T R A C T}

\begin{tabular}{|l|}
\hline K e y w o r d s \\
Socio-personal, \\
Socio-economic, \\
Small scale, Pig \\
farmers
\end{tabular}

\section{Introduction}

Pig rearing is one the important activities in the rural economy of Manipur, a far while northeastern state of India, providing additional source of income to small scale farmers including marginal and landless farm

women. The rural women play a significant
Pig farming is dispensable to the tribal folks of Manipur, India. In this study, we tried to establish baseline information on the socio-personal and socio-economical status of small scale tribal pig farmers in the state. Altogether, 400 tribal pig farmers, rearing $\geq 2$ pigs were selected randomly and interviewed from 4 blocks of Senapati district, Manipur. The study showed that majority of tribal pig farmers $(69.75 \%)$ belonged to middle age groups (31-50 years), followed by $19.25 \%$ young age groups (up to 30 years), and $11 \%$ old age groups (> 50 years), respectively. Most of pig farmers were female $(54 \%)$ while, male populations occupy $46 \%$. The study also revealed that $72.25 \%$ of pig farmers belonged to medium size family (6-9) followed by $25.25 \%$ (small size family- up to 5) and only $2.50 \%$ large size family (>9). It was also observed that majority of pig farmers have high school level education $(28 \%)$ followed by middle school $(25.75 \%)$, intermediate $(14.25 \%)$, graduate and above (12\%), primary and illiterate (both $10 \%$ ). The block wise distribution of pig farmers according to social participation showed that the majority (53.75\%) of the pig farmers of all four blocks have high social participation followed by medium $(33.25 \%)$ and low $(13.00 \%)$ level of participation. Majority (49.25\%) of the respondents belonged to low level of extension contact followed by medium $(39.25 \%)$ and high $(11.50 \%)$ level, whereas majority $(48.50 \%)$ of the respondents has low mass media contact while 36.50 and $11.50 \%$ belonged to medium and high level media contact, respectively. It was also observed that higher numbers of pig farmer rears 5-7 pigs $(63.75 \%)$ followed by rearing above 7 pigs $(19.75 \%)$ and rearing upto 4 pigs $(16.50 \%)$. It is always important to know the socio-economic status of small scale tribal pig farmers for any interventions to uplift pig production for enhancing livelihood of farmers and household food security. role in livestock rearing and are directly involved in most of the operations relating to feeding, breeding, management and health care of the animals. Most of the tribal households have one or more livestock rearing activities with minimum investment resulting into improvement of their socio-economic status. Piggery is a very good and easy source 
of regular occupation for the majority of people. The pig is a quick growing animal and important source of animal protein in the diets of many people at comparatively cheaper cost on account of its prolificacy, shorter generation interval, faster growth rate, better feed conversion efficiency, high dressing percentage and low maintenance cost. Pig occupies a unique position in the region since its rearing is socio-culturally intermingled with livelihood of tribal folk. In tribal areas, meat of any kind is acceptable without any religious taboo but a special preference is given to pork.

The Senapati district of Manipur has the highest tribal population $(2,83,621)$ amongst all the hill districts of the state and the highest density of population with 87 persons/ sq.km with a literacy rate of $45.11 \%$. It comprises of 1,46,548 male and 1,37,073 female (Anon, 2008). While considering the importance of pig farming in the state, the social empowerment through better livelihood is very important. Thus, we intend to map out the socio-economic profile of the existing farmers of the region through this pilot survey, with an aim to place the status to related functionaries for future programme.

\section{Materials and Methods}

The present study was carried out at 20 randomly selected villages from 4 Tribal Development Blocks namely Kangpokpi, Saitu Gamphazol, Purul and Mao Maram of Senapati district of Manipur covering five villages in each block. One household having a minimum of two pigs represents one respondent. A total of 100 small scale pig farmers were selected from each block. Finally, 400 small scale tribal pig farmers were randomly selected from 4 selected blocks for the present study during 2014-15. The data were collected and tabulated for statistical analysis as per Snedecor and Cochran (1989).

\section{Results and Discussion}

\section{Socio-personal profile}

Age

The block wise distribution of pig farmers according to age has been presented in Table 1 and depicted through Figure 1 clearly indicated that the majority of the pig farmers of all four blocks belong to middle age groups (63 to 76\%) followed by young age groups (13 to $28 \%$ ) and old age groups (9 to $13 \%$ ) with pooled value of $69.75,19.25$ and $11.00 \%$, respectively belonging to middle age (31-50 years), young age (upto 30 years) and old age (>50 years), respectively.

The average age of pig farmers of all the twenty villages belonging to four blocks had also been estimated and presented in Table 6 . There was not much difference in the age of pig farmers of different villages and was found to be nonsignificant statistically as tested by analysis of variance (Table 5). The average age of pig farmers ranged from 34.55 +1.79 years (Haipi village) to $41.55+1.61$ years (Koide village) as evident from Table 6.

It is evident from the table that majority of the pig farmers belong to middle aged group (3150 years) and this is the age group which has enthusiasm for livestock farming for their livelihood and nutritional security. The present finding was also supported by Pandey (1996), Verma (2003) and Mahto (2008) who also noticed that majority of the pig farmers were belonging to middle aged group. Similar trends were also reported in others species by Singh (1989) and Kumari (2014).

\section{Sex}

Table 2 and Figure 2 revealed that female looked after the pig farming more in comparison to male. The pooled value was 54 
and $46 \%$ by female and male respondents, respectively. At block level also similar trend was observed in each block (Table 2 and Figure 2). The female and male pig farmers were 55 and 45\%, 57 and 43\%, 53 and 47\% and 51 and $49 \%$ in Kangpokpi, Saitu Gamphazol, Purul and Mao Maram block, respectively. However, it was not a sole operation of any single individual in the family. In fact, all the family members contributed in some way or the other in the pig farming activities. The women were mainly responsible for cleaning of pig sty, providing feed and water to animals and taking care of sick and pregnant animals.

The possible explanation for more women involvement in pig farming activities could be due to the fact that the women might be devoting more time in household works as compared to male.

It means female are devoting more times nearby their houses resulted into more attention on pig farming activities because pig sty is situated nearby own houses. The male were doing the jobs of procuring and marketing of animals besides going out for earning daily wages within and/ or outside villages.

The present finding confirms to earlier findings of Kumari et al., (1988) and Arya and Jamal (1992) who also observed 80-90 percent involvement of farm women in animal husbandry activities. On the contrary, it does not confirm to the study of Verma (2003) who reported that the female handled livestock activities to the extent of $28.75 \%$ only.

\section{Family size}

The number of members in a family currently living together indicates the size of family. Table 3 and Figure 3 showed that $72.25 \%$ of pig farmers pooled over all the twenty villages of four blocks belonged to medium size family (6-9) followed by $25.25 \%$ (small size familyupto 5) and only $2.50 \%$ were large size family $(>9)$. The block wise distribution of pig farmers belonging to small, medium and large family size were found to be 29,65 and 6\%; 27, 71 and 2\%;25, 74 and $1 \%$ and 20, 79 and $1 \%$ in Kangpokpi, Saitu Gamphazol, Purul and Mao Maram block, respectively.

Village wise average family size of pig farmers was also calculated and presented in Table 6. Analysis of variance (Table 5) showed nonsignificant effect of villages on family size of pig farmers. The average family size ranged between $6.15+0.42$ (Hengbung) and $7.25+0.34$ (Willong) which is indicative of medium family size of pig farmers. This finding is in accordance with the findings of Pandey (1996) and Verma (2003) who also reported the average size of family varying between 5 to 8 persons.

\section{Education}

Education status has been considered as an important factor for socio-economic upliftment of the society. Education is generally believed to have the effect on widening the mental horizon of a person and thereby prepares or predisposes him to be receptive to new ideas.

The distribution of respondents according education is depicted in Table 4 and Figure 4 which showed that majority of the pig farmers of Kangpokpi block (37\%) and Saitu Gamphazol block (35\%) were IX and X passed whereas majority of pig farmers belonging to Purul block (26\%) and Mao Maram block (25\%) were VI to VIII passed. On the contrary, higher education (graduate and above) was recorded in Purul block (16\%) and Mao Maram block (14\%) in comparison to Kangpokpi block (8\%) and Saitu Gamphazol block (10\%). 
Table.1 Distribution of pig farmers according to age

\begin{tabular}{|r|c|c|c|c|c|c|c|c|c|c|}
\hline $\begin{array}{l}\text { Age } \\
\text { (in }\end{array}$ & \multicolumn{2}{|c|}{$\begin{array}{c}\text { Kangpokpi } \\
\text { year) }\end{array}$} & \multicolumn{2}{|c|}{$\begin{array}{c}\text { Saitu Gamphazol } \\
\text { Block }\end{array}$} & \multicolumn{2}{c|}{$\begin{array}{c}\text { Purul } \\
\text { block }\end{array}$} & \multicolumn{2}{c|}{$\begin{array}{c}\text { Mao Maram } \\
\text { block }\end{array}$} & \multicolumn{2}{|c|}{ Pooled } \\
\hline Upto 30 & 28 & 28 & F & $\%$ & F & $\%$ & F & $\%$ & F & $\%$ \\
\hline $\mathbf{3 1 - 5 0}$ & 63 & 63 & 67 & 67 & 73 & 73 & 76 & 76 & 279 & 69.75 \\
\hline$>\mathbf{5 0}$ & 9 & 9 & 11 & 11 & 13 & 13 & 11 & 11 & 44 & 11.00 \\
\hline Total & 100 & 100 & 100 & 100 & 100 & 100 & 100 & 100 & 400 & 100 \\
\hline
\end{tabular}

Table.2 Distribution of pig farmers according to sex

\begin{tabular}{|l|c|c|c|c|c|c|c|c|c|c|}
\hline \multirow{2}{*}{ Sex } & \multicolumn{2}{|c|}{$\begin{array}{c}\text { Kangpokpi } \\
\text { Block }\end{array}$} & \multicolumn{2}{c|}{$\begin{array}{c}\text { Saitu Gamphazol } \\
\text { block }\end{array}$} & \multicolumn{2}{c|}{$\begin{array}{c}\text { Purul } \\
\text { block }\end{array}$} & \multicolumn{2}{c|}{$\begin{array}{c}\text { Mao Maram } \\
\text { block }\end{array}$} & \multicolumn{2}{|c|}{ Pooled } \\
\cline { 2 - 11 } & F & $\%$ & F & $\%$ & F & $\%$ & F & $\%$ & F & $\%$ \\
\hline Male & 45 & 45 & 43 & 43 & 47 & 47 & 49 & 49 & 184 & 46 \\
\hline Female & 55 & 55 & 57 & 57 & 53 & 53 & 51 & 51 & 216 & 54 \\
\hline Total & 100 & 100 & 100 & 100 & 100 & 100 & 100 & 100 & 400 & 100 \\
\hline
\end{tabular}

Table.3 Distribution of pig farmers according to family size

\begin{tabular}{|c|c|c|c|c|c|c|c|c|c|c|}
\hline \multirow[t]{2}{*}{$\begin{array}{l}\text { Family size } \\
\text { (in no.) }\end{array}$} & \multicolumn{2}{|c|}{$\begin{array}{c}\text { Kangpokpi } \\
\text { Block }\end{array}$} & \multicolumn{2}{|c|}{$\begin{array}{c}\text { Saitu } \\
\text { Gamphazol } \\
\text { block }\end{array}$} & \multicolumn{2}{|c|}{$\begin{array}{l}\text { Purul } \\
\text { block }\end{array}$} & \multicolumn{2}{|c|}{$\begin{array}{c}\text { Mao } \\
\text { Maram } \\
\text { block }\end{array}$} & \multicolumn{2}{|c|}{ Pooled } \\
\hline & $\mathrm{F}$ & $\%$ & $\mathrm{~F}$ & $\%$ & $\mathrm{~F}$ & $\%$ & $\mathrm{~F}$ & $\%$ & $\mathrm{~F}$ & $\%$ \\
\hline Small ( 5 and below) & 29 & 29 & 27 & 27 & 25 & 25 & 20 & 20 & 101 & 25.25 \\
\hline Medium (6 - 9) & 65 & 65 & 71 & 71 & 74 & 74 & 79 & 79 & 289 & 72.25 \\
\hline Large (> 9) & 6 & 6 & 2 & 2 & 1 & 1 & 1 & 1 & 10 & 2.50 \\
\hline Total & 100 & 100 & 100 & 100 & 100 & 100 & 100 & 100 & 400 & 100 \\
\hline
\end{tabular}

Table.4 Distribution of pig farmers according to education

\begin{tabular}{|c|c|c|c|c|c|c|c|c|c|c|}
\hline \multirow[t]{2}{*}{ Education } & \multicolumn{2}{|c|}{$\begin{array}{c}\text { Kangpokpi } \\
\text { Block }\end{array}$} & \multicolumn{2}{|c|}{$\begin{array}{c}\text { Saitu Gamphazol } \\
\text { Block }\end{array}$} & \multicolumn{2}{|c|}{$\begin{array}{l}\text { Purul } \\
\text { Block }\end{array}$} & \multicolumn{2}{|c|}{$\begin{array}{l}\text { Mao Maram } \\
\text { Block }\end{array}$} & \multicolumn{2}{|c|}{ Pooled } \\
\hline & $\mathrm{F}$ & $\%$ & $\mathrm{~F}$ & $\%$ & $\mathrm{~F}$ & $\%$ & $\mathrm{~F}$ & $\%$ & $\mathrm{~F}$ & $\%$ \\
\hline Illiterate & 15 & 15 & 9 & 9 & 8 & 8 & 8 & 8 & 40 & 10 \\
\hline Primary (i -v) & 4 & 4 & 3 & 3 & 17 & 17 & 16 & 16 & 40 & 10 \\
\hline Middle (vi - viii) & 20 & 20 & 32 & 32 & 26 & 26 & 25 & 25 & 103 & 25.75 \\
\hline High $(i x-x)$ & 37 & 37 & 35 & 35 & 18 & 18 & 22 & 22 & 112 & 28 \\
\hline College (xi -xii) & 16 & 16 & 11 & 11 & 15 & 15 & 15 & 15 & 57 & 14.25 \\
\hline $\begin{array}{l}\text { Graduate \& } \\
\text { above }\end{array}$ & 8 & 8 & 10 & 10 & 16 & 16 & 14 & 14 & 48 & 12 \\
\hline Total & 100 & 100 & 100 & 100 & 100 & 100 & 100 & 100 & 400 & 100 \\
\hline
\end{tabular}


Table.5 Analysis of variance showing the effect of villages on various socio-personal and socioeconomic variables of respondents

\begin{tabular}{|c|c|c|c|c|}
\hline Source of variation & \multirow{2}{*}{$\mathbf{d f}$} & \multicolumn{3}{|c|}{ Mean Square. } \\
\cline { 3 - 5 } & & Age & Family size & Herd size \\
\hline Between villages & 19 & $73.91^{\text {NS }}$ & 1.30 & $24.13 * *$ \\
\hline Within villages & 380 & 71.48 & 2.72 & 1.96 \\
\hline & NS = Nonsignificant; & $* * \mathbf{p}<\mathbf{0 . 0 1}$ \\
\hline
\end{tabular}

Table.6 Villages wise average socio-personal and socio-economic variables of respondents

\begin{tabular}{|c|c|c|c|}
\hline Villages & Age (years) & Family size (nos.) & Herd size (nos.) \\
\hline Taphou Kuki & $38.75 \pm 2.18$ & $6.65 \pm 0.39$ & $5.05 \pm 0.26^{\mathrm{a}}$ \\
\hline South Changoubung & $35.05 \pm 1.91$ & $6.60 \pm 0.45$ & $4.85 \pm 0.25^{\mathrm{a}}$ \\
\hline Kangpokpi & $39.25 \pm 1.57$ & $6.90 \pm 0.38$ & $5.10 \pm 0.23^{a}$ \\
\hline Hengbung & $38.85 \pm 2.58$ & $6.15 \pm 0.42$ & $5.20 \pm 0.27^{\mathrm{a}}$ \\
\hline Haipi & $34.55 \pm 1.79$ & $6.55 \pm 0.52$ & $4.95 \pm 0.25^{\mathrm{a}}$ \\
\hline Sapormeina & $40.25 \pm 2.03$ & $6.95+0.29$ & $5.05 \pm 0.19^{\mathrm{a}}$ \\
\hline Motbung & $37.95 \pm 2.09$ & $6.85 \pm 0.33$ & $5.05 \pm 0.28^{a}$ \\
\hline Lhangkichoi & $38.35 \pm 2.30$ & $6.35 \pm 0.37$ & $4.95 \pm 0.18^{a}$ \\
\hline Leikot & $36.05 \pm 1.96$ & $6.25 \pm 0.45$ & $5.10 \pm 0.24^{\mathrm{a}}$ \\
\hline Khengjang & $38.95 \pm 1.76$ & $6.45 \pm 0.39$ & $5.15 \pm 0.26^{\mathrm{a}}$ \\
\hline Purul Atongba & $41.25 \pm 1.81$ & $6.65 \pm 0.33$ & $7.20 \pm 0.54^{b}$ \\
\hline Purul Akutpa & $38.55 \pm 1.91$ & $6.70 \pm 0.33$ & $7.05 \pm 0.36^{b}$ \\
\hline Oinam & $39.90 \pm 1.83$ & $6.50 \pm 0.36$ & $7.05 \pm 0.28^{b}$ \\
\hline Koide Mathak & $41.55 \pm 1.61$ & $6.70 \pm 0.34$ & $7.25 \pm 0.35^{b}$ \\
\hline Koide Makha & $40.70 \pm 1.86$ & $6.80 \pm 0.31$ & $7.55 \pm 0.28^{b}$ \\
\hline Willong & $39.70 \pm 1.63$ & $7.25 \pm 0.34$ & $7.05 \pm 0.37^{b}$ \\
\hline Tadubi & $41.35 \pm 1.54$ & $6.60 \pm 0.31$ & $7.25 \pm 0.35^{b}$ \\
\hline Maram bazar & $39.20 \pm 1.84$ & $6.70 \pm 0.33$ & $7.05 \pm 0.39^{b}$ \\
\hline Mao Pungdung & $40.05 \pm 1.54$ & $6.85 \pm 0.30$ & $6.65 \pm 0.29^{b}$ \\
\hline Katomei & $39.50 \pm 1.69$ & $6.85 \pm 0.34$ & $7.45 \pm 0.41^{b}$ \\
\hline CD value & $\mathrm{NS}$ & NS & 0.87 \\
\hline
\end{tabular}

Table.7 Distribution of pig farmers according to social participation

\begin{tabular}{|c|c|c|c|c|c|c|c|c|c|c|}
\hline \multirow{2}{*}{$\begin{array}{l}\text { Social } \\
\text { participati } \\
\text { on }\end{array}$} & \multicolumn{2}{|c|}{$\begin{array}{l}\text { Kangpokpi } \\
\text { Block }\end{array}$} & \multicolumn{2}{|c|}{$\begin{array}{c}\text { Saitu Gamphazol } \\
\text { block }\end{array}$} & \multicolumn{2}{|c|}{$\begin{array}{l}\text { Purul } \\
\text { block }\end{array}$} & \multicolumn{2}{|c|}{$\begin{array}{c}\text { Mao Maram } \\
\text { block }\end{array}$} & \multicolumn{2}{|c|}{ Pooled } \\
\hline & $\mathrm{F}$ & $\%$ & $\mathrm{~F}$ & $\%$ & $\mathrm{~F}$ & $\%$ & $\mathrm{~F}$ & $\%$ & $\mathrm{~F}$ & $\%$ \\
\hline Low & 14 & 14 & 12 & 12 & 14 & 14 & 12 & 12 & 52 & 13.00 \\
\hline Medium & 32 & 32 & 35 & 35 & 31 & 31 & 35 & 35 & 133 & 33.25 \\
\hline High & 54 & 54 & 53 & 53 & 55 & 55 & 53 & 53 & 215 & 53.75 \\
\hline Total & 100 & 100 & 100 & 100 & 100 & 100 & 100 & 100 & 400 & 100 \\
\hline
\end{tabular}


Table.8 Distribution of pig farmers according to extension contact

\begin{tabular}{|l|c|c|c|c|c|c|c|c|c|c|}
\hline $\begin{array}{l}\text { Extensio } \\
\text { n contact }\end{array}$ & \multicolumn{2}{|c|}{$\begin{array}{c}\text { Kangpokpi } \\
\text { Block }\end{array}$} & \multicolumn{2}{c|}{$\begin{array}{c}\text { Saitu } \\
\text { Gamphazol } \\
\text { block }\end{array}$} & \multicolumn{2}{c|}{$\begin{array}{c}\text { Purul } \\
\text { block }\end{array}$} & \multicolumn{2}{c|}{$\begin{array}{c}\text { Mao Maram } \\
\text { block }\end{array}$} & \multicolumn{2}{|c|}{ Pooled } \\
\cline { 2 - 11 } & F & $\%$ & F & $\%$ & F & $\%$ & F & $\%$ & F & $\%$ \\
\hline Low & 58 & 58 & 57 & 57 & 41 & 41 & 41 & 41 & 197 & 49.25 \\
\hline Medium & 31 & 31 & 34 & 34 & 45 & 45 & 47 & 47 & 157 & 39.25 \\
\hline High & 11 & 11 & 9 & 9 & 14 & 14 & 12 & 12 & 46 & 11.50 \\
\hline Total & 100 & 100 & 100 & 100 & 100 & 100 & 100 & 100 & 400 & 100 \\
\hline
\end{tabular}

Table.9 Distribution of pig farmers according to mass media contact

\begin{tabular}{|c|c|c|c|c|c|c|c|c|c|c|}
\hline \multirow[t]{2}{*}{$\begin{array}{l}\text { Mass } \\
\text { media } \\
\text { contact }\end{array}$} & \multicolumn{2}{|c|}{$\begin{array}{c}\text { Kangpokpi } \\
\text { Block }\end{array}$} & \multicolumn{2}{|c|}{$\begin{array}{c}\text { Saitu } \\
\text { Gamphazol } \\
\text { block }\end{array}$} & \multicolumn{2}{|c|}{$\begin{array}{l}\text { Purul } \\
\text { block }\end{array}$} & \multicolumn{2}{|c|}{$\begin{array}{c}\text { Mao } \\
\text { Maram } \\
\text { block }\end{array}$} & \multicolumn{2}{|c|}{ Pooled } \\
\hline & $\mathrm{F}$ & $\%$ & $\mathrm{~F}$ & $\%$ & $\mathrm{~F}$ & $\%$ & $\mathrm{~F}$ & $\%$ & $\mathrm{~F}$ & $\%$ \\
\hline Low & 57 & 57 & 57 & 57 & 42 & 42 & 38 & 38 & 194 & 48.50 \\
\hline Medium & 30 & 30 & 29 & 29 & 41 & 41 & 46 & 46 & 146 & 36.50 \\
\hline High & 13 & 13 & 14 & 14 & 17 & 17 & 16 & 16 & 60 & 15.00 \\
\hline Total & 100 & 100 & 100 & 100 & 100 & 100 & 100 & 100 & 400 & 100 \\
\hline
\end{tabular}

Table.10 Distribution of pig farmers according to herd size

\begin{tabular}{|r|c|c|c|c|c|c|c|c|c|c|}
\hline $\begin{array}{l}\text { Herd size } \\
\text { (in no.) }\end{array}$ & \multicolumn{2}{|c|}{$\begin{array}{c}\text { Kangpokpi } \\
\text { Block }\end{array}$} & \multicolumn{2}{|c|}{$\begin{array}{c}\text { Saitu Gamphazol } \\
\text { block }\end{array}$} & \multicolumn{2}{|c|}{$\begin{array}{c}\text { Purul } \\
\text { block }\end{array}$} & \multicolumn{2}{|c|}{$\begin{array}{c}\text { Mao } \\
\text { Maram } \\
\text { block }\end{array}$} & \multicolumn{3}{|c|}{ Pooled } \\
\cline { 2 - 11 } & F & $\%$ & F & $\%$ & F & $\%$ & F & $\%$ & F & $\%$ \\
\hline Upto 4 & 33 & 33 & 27 & 27 & 3 & 3 & 3 & 3 & 66 & 16.50 \\
\hline $\mathbf{5}-7$ & 67 & 67 & 73 & 73 & 59 & 59 & 56 & 56 & 255 & 63.75 \\
\hline$>7$ & - & - & - & - & 38 & 38 & 41 & 41 & 79 & 19.75 \\
\hline Total & 100 & 100 & 100 & 100 & 100 & 100 & 100 & 100 & 400 & 100 \\
\hline
\end{tabular}

Fig.1 Distribution of pig farmers according to age

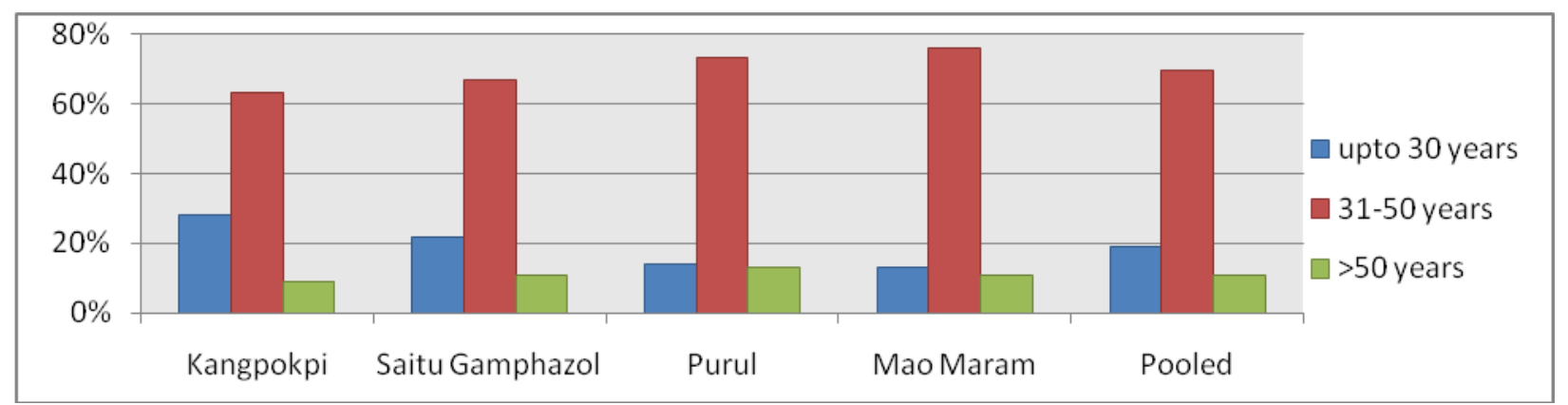


Fig.2 Distribution of pig farmers according to sex

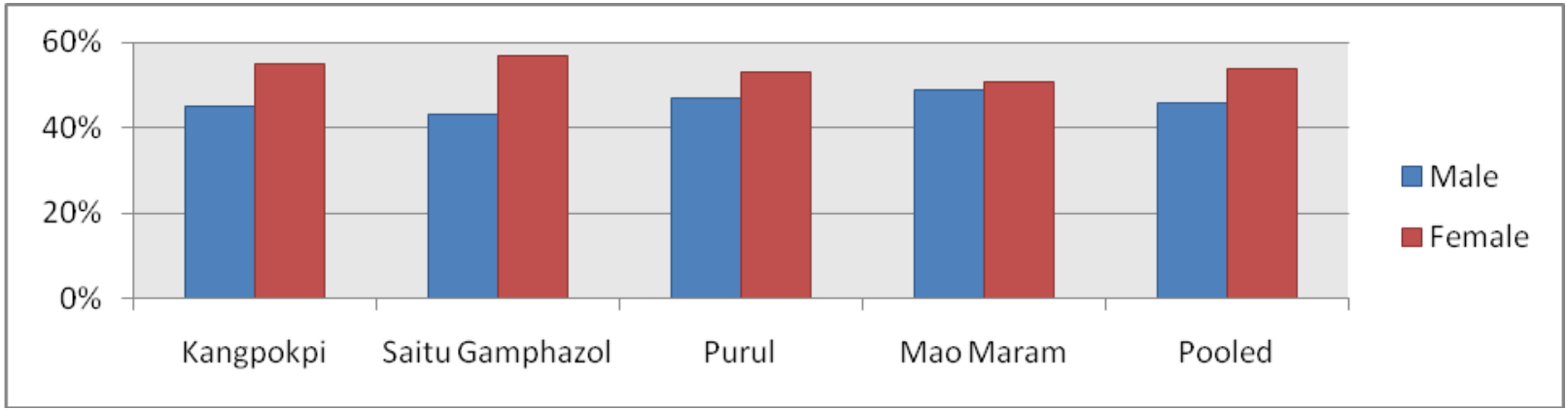

Fig.3 Distribution of pig farmers according to family size

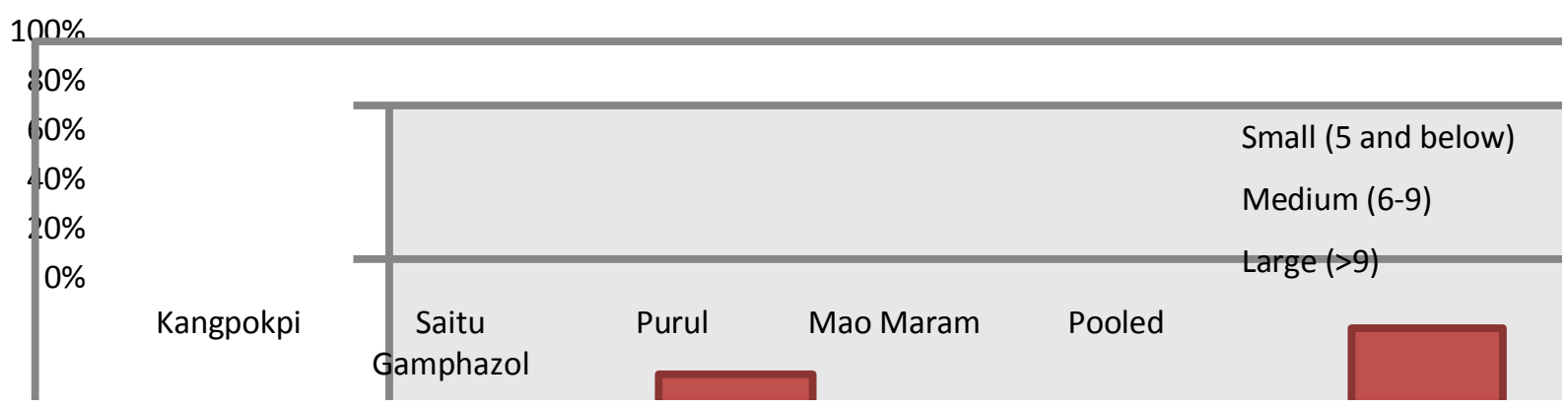

Fig.4 Distribution of pig farmers according to education

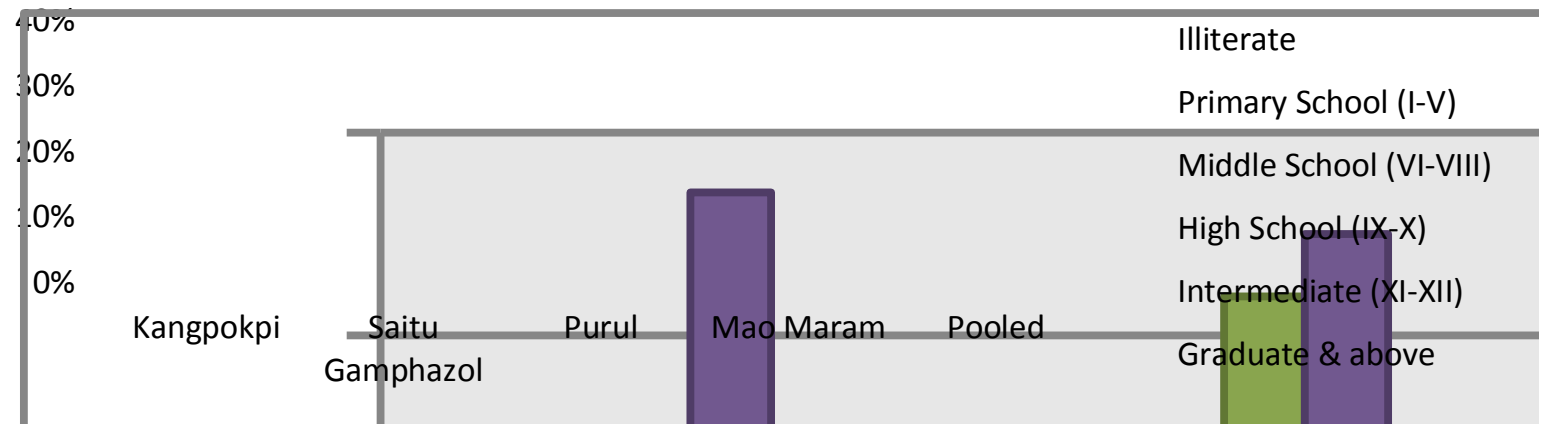

Fig.5 Distribution of pig farmers according to herd size

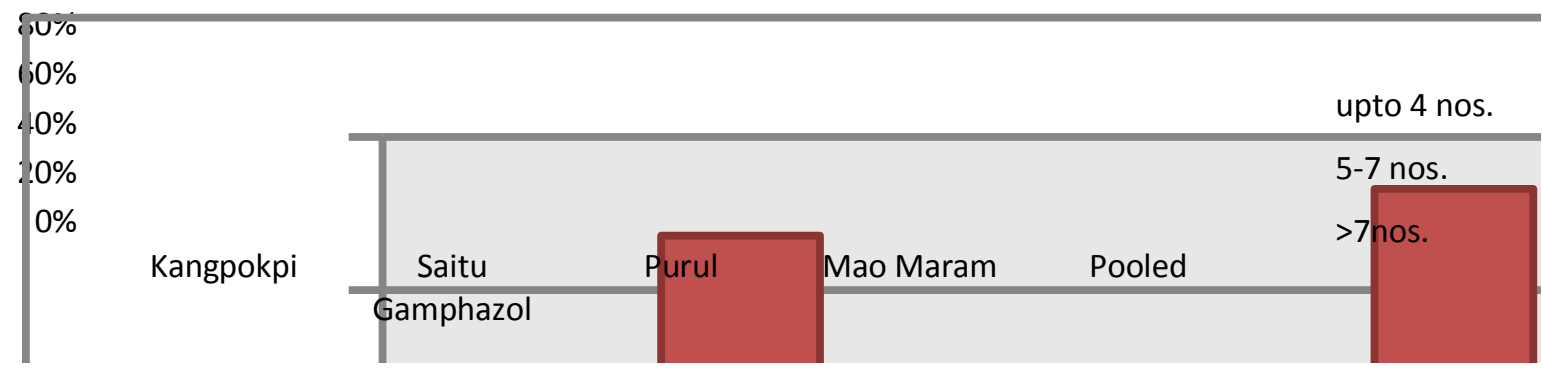


The pooled value showed higher pig farmers belonging to high school education (28\%) followed by middle school (25.75\%), intermediate $(14.25 \%)$, graduate and above (12\%), primary and illiterate (both $10 \%$ ).

It can be inferred from the table that the educational level of pig farmers under the present study was low. Low levels of education among tribals were also reported by Oraon (1989), Pandey (1996) and Mahto (2008). The low level of education may be due to the fact that the pig farmers generally belonged to weaker section of society. Lack of educational facilities, low income, and language problem faced by the tribals and poor communication facilities may also have resulted in poor literacy rate. The economic pressure could be one of the contributing factors for their poor literacy as they feel that if their children are engaged in some kind of subsidiary occupation than this will add to their income.

\section{Social participation}

The block wise distribution of pig farmers according to social participation has been presented in Table 7 which clearly indicated that the majority $(53.75 \%)$ of the pig farmers of all four blocks have high social participation followed by medium $(33.25 \%)$ and low (13.00\%) level of participation. The high level of social participation indicates the cohesiveness of tribal social structure. It was observed that people always participate in large numbers during religious, socio-cultural events/ festivals such as marriage, death ceremony etc. in the rural villages. Agricultural activities such as ploughing, seed sowing, harvesting etc. are done in groups in a festive ways. It also indicates that chances of adoption of new technologies are high.

The findings from the present study are with accordance to the findings of Singh (1980) and Singh (1983) who also observed high social participation of respondents on different agricultural and livestock activities. High social participation of farmers was also reported by Kumar et al., (2002) in north eastern (NE) states of the country who noticed high $(53 \%)$ social participation followed by Medium (30.75\%) and low (16.25\%) social participation of respondents. On the contrary, Verma (2003) and Kumari (2014) noticed low social participation of respondents. Kumari (2014) recorded low, medium and high social participation to be $60.67,38.00$ and $1.33 \%$, respectively. Low social participation was also reported by Verma (2003) who also got $85.00,8.75$ and $6.25 \%$ social participation of respondents in low, medium and high levels, respectively among tribal pig farmers of Ranchi district of Jharkhand. He further indicated that low social participation was mainly due to fact that the pig farmers of his study areas were belonged to low rung society which restricted their social participation.

\section{Extension and mass media contact}

The pig farmer's closeness with the extension workers is termed as extension contact. The block wise distribution of pig farmers according to extension and social media contact has been presented in Table 8 and Table 9, respectively. Table 8 revealed that majority $(49.25 \%)$ of the respondents belonged to low level of extension contact followed by medium (39.25\%) and high $(11.50 \%)$ level. It was further observed that majority $(48.50 \%)$ of the respondents has low mass media contact while 36.50 and $11.50 \%$ belonged to medium and high level media contact, respectively (Table 9). The low level of extension and mass media contact might be due to the fact that they belonged to resource poor strata of society and are not able to visit and contact various extension and media facilities. And also the extension and media agencies failed to reach the needy poor 
farmers of the district due to poor connectivity and negligence due to which there is lack of awareness of various Government schemes for the poor farmers. This hinders the adoption of various newly developed technologies on animal husbandry and agriculture.

The present findings were in agreement with those of Kumar et al., (2002), Verma (2003), Seth (2004), Jha (2012) and Kumari (2014) during their various studies who also observed less extension contact of respondents. Kumar et al., (2002), in their study, has reported the similar pattern amongst the pig farmers of NE states. It was reported that 64,25 and $11 \%$ of respondents belonged to low, medium and high level of extension contact, respectively while 59.50, 26.75 and $13.75 \%$ of respondents belonged to low, medium and high level of media contact, respectively. On the contrary, Oraon (1989) reported high extension contact amongst the tribal of Ranchi district of Jharkhand in his study.

It is also worth mentioning that the extension and mass media contact not only brings awareness among farmers but also help them to learn scientific, useful and profitable farm practices. It also helps them in acquiring new knowledge and analyzing the new ideas leading to adoption of improved practices. Therefore, every effort should be made by extension agencies to make frequent contact with the farmers.

\section{Socio-economic variables}

\section{Herd size}

The distribution of pig farmers according to herd size of pigs has been depicted through Figure 5 and Table 10. It indicated that higher numbers of pig farmers were maintaining 5-7 pigs $(63.75 \%)$ followed by maintaining above
7 pigs $(19.75 \%)$ and maintaining upto 4 pigs (16.50\%) on data pooled over all the four blocks.

The village wise herd strength of pigs has been presented in Table 6. Analysis of variance (Table 5) showed significant effect of villages on herd size of pigs maintained by farmers. Further, critical difference test presented in Table 6 indicated significantly lowest herd size of pigs of villages belonging to Kangpokpi and Saitu Gamphazol blocks which did not differ significantly among themselves. The values ranged between 4.85 +0.25 and $5.20+0.27$ (Table 6). On contrary, the herd strength of pig farmers belonging to Purul and Mao Maram blocks had significantly higher herd size of pigs than former two blocks mentioned above. The differences among ten villages of latter two blocks were nonsignificant statistically except Koide Makha $(7.55+0.28)$ which differs significantly from all the villages under study (Table 6). The values in ten villages of latter two blocks varied from $6.65+0.29$ (Mao Pungdung) to $7.45+0.41$ (Katomei).

The present findings indicated slightly higher herd strength of pigs than those noticed by Pandey (1996) and Verma (2003) who reported average herd strength of pigs to be 3 to 4 under their study. On the contrary, Mahto (2008) reported higher herd strength of pig in organized and un-organised herd to be 23.76 +6.48 and $14.60+6.95$, respectively.

\section{Land holding}

The size of land holding has an important role in deciding the family status in the village. The present study has not done a detail assessment on this topic in the present study area. There is a distinct but different social set up amongst different communities in the district. Only a broader view is being presented for the sake of understanding nature 
of land holding. Senapati district, being a hill district, percentage of individual land ownership is less as majority of the land are community owned. And thus, the respondents were marginal as well as landless farmers. There was preponderance of marginal farmers in the Senapati district of Manipur. The low land holding amongst the respondents might be due to the fact that the entire district is upland hilly terrain as well as increased in population and family numbers which resulted in fragmentation of land holdings year by year. And, the lower socio-economic status of pig farmers could also be the other probable reason for low land holdings of land.

The pig farmers of the study areas belonged to the lowest socio-economic strata which have no means to undertake scientific pig farming. Pigs are potential source of animal proteins and avenues for additional income and employment that can improve the livelihood in a sustainable manner. Piggery has the potential to have a positive impact on the livelihood of resource poor, underprivileged, landless and marginal tribal farmers.

\section{Acknowledgements}

The authors are thankful to the Senior Scientist \& Head, Krishi Vigyan Kendra, Hengbung, Senapati district, Manipur for providing facilities for carrying out the present study and for giving constant support and encouragement.

\section{References}

Anonymous. (2008). Statistical Abstract Manipur, 2007. Directorate of Economics and Statistics, Manipur.

Arya, H.P.S. and Jamal, S. 1992. Approaching rural women, the extension target for dairy development. Interaction, 10 (2):163-172.
Jha, A.K. 2012. Impact of animal husbandry components of NAIP in Dumka district. M.V.Sc. Thesis, Birsa Agricultural University, Ranchi.

Kumar, Rajesh, Pal, P.P., Prasad, K and Prakash, N. 2002. Modernizing Tribal Piggery - A Delineated Approach. Research Bulletin No. 47. ICAR Research Complex for NEH Region, Shillong, Meghalaya.

Kumari, A., Verma, I., Sinha, I. and Srinivasan, N. (1988). The churning point - A case study of farm movement in dairying in Bihar. Paper presented at International Conference on appropriate Agricultural Technologies for farm movement, ICAR, New Delhi, Nov. 30 - Dec.4.

Kumari, N. (2014). Study on status and constraints of Goat rearing in and around of Ranchi district. M.V.Sc. Thesis, Birsa Agricultural University, Ranchi.

Mahto, V.K. (2008). Economic evaluation of pig farming in organised and unorganized farm in Ranchi district of Jharkhand. M.V.Sc. Thesis, Birsa Agricultural University, Ranchi.

Oraon, J. 1989. Economic motivation and adoption of improved farming practices in Belangi village. M.V.Sc. Thesis (unpublished), Birsa Agricultural University, Ranchi. Bihar.

Pandey, A.K. (1996). A comparative study of livestock rearing system among tribals and non-tribals in Chotanagpur region of Bihar. Ph.D. Thesis submitted to National Dairy Research Institute (NDRI), Karnal.

Singh, B.K. 1983. A study of sociopsychodynamics in a dairy progressive and a dairy non-progressive village. M.Sc. Thesis, Kurukshetra University, Kurukshetra.

Singh, R.K. 1980. Income and employment potential of dairy enterprise on mixed 
farms (Abstract). Indian Journal of Agriculture Economics, 35 (4): 165.

Singh, S. (1989). A study of differential knowledge and adoption of Dairy innovations by farmers in adopted village of Dairy Extension, National Dairy Research Institute (NDRI), Karnal, M.Sc. Thesis, NDRI, Karnal.
Snedecor, G.W. and Cochran, W.G. (1989). Statistical Methods. $8^{\text {th }}$ Edn. The Iowa State University Press, Ames, Iowa, United State of America.

Verma, M.K. (2003). Pig farming practices of tribal pig farmers of Ranchi district. M.V.Sc. Thesis, Birsa Agricultural University, Ranchi.

\section{How to cite this article:}

Muhindro Singh N., Soibam Basanta Singh and Soibam Khogen Singh. 2019. Small Scale Pig Farming in Manipur, India: A Study on Socio-Personal and Socio-Economical Status of the Small Scale Tribal Farming Community. Int.J.Curr.Microbiol.App.Sci. 8(08): 1158-1168. doi: https://doi.org/10.20546/ijcmas.2019.808.136 